\title{
DAMPAK RELOKASI PASAR BAGI PELAKU EKONOMI DI KOTA JAMBI (Studi kasus pasar Angsoduo)
}

\author{
Oleh: \\ Yunie Rahayu ${ }^{1}$ \\ Dosen STIE Muhammadiyah Jambi ${ }^{1}$ \\ Yunie.soleh@gmail.com \\ Adi Putra ${ }^{2}$ \\ Dosen STIE Muhammadiyah Jambi² \\ putramm@yahoo.co.id \\ Nurdin ${ }^{3}$ \\ Dosen STIE Muhammadiyah Jambi ${ }^{3}$ \\ oedin69@yahoo.co.id \\ Indria Mayesti ${ }^{4}$ \\ Dosen STIE Muhammadiyah Jambi ${ }^{4}$ \\ Mayestiindria8@gmail.com \\ Irma Nelly 5 \\ Dosen STIE Muhammadiyah Jambi ${ }^{5}$

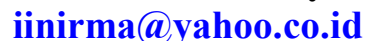 \\ Prima Audia Daniel 6 \\ Dosen STIE Muhammadiyah Jambi ${ }^{6}$ \\ primaaudia@ymail.com
}

Ringkasan

Relokasi suatu pasar tradisional ke tempat baru tentu membawa dampak bagi para pelakunya. Hal ini juga berlaku bagi direlokasinya Pasar Angso Duo di Kota Jambi. Walaupun lokasi Pasar Angso Duo baru terletak di sebelah kanan dari Pasar Angsoduo lama dan hanya berjarak 100 meter, namun relokasi ini membawa dampak baik bagi pedagang, masyarakat dan pemerintah Kota dan Propinsi Jambi.

Relokasi pasar Angsoduo baru ini membawa dampak social dan ekonomi yang positif terhadap pedagang, masyarakat dan pemerintah. Pendapatan pedagang meningkat dikarenakan kondisi pasar yang bersih, pengaturan lapak yang rapi, lahan parkir yang luas membuat jumlah pembeli meningkat. Hal ini menyebabkan pendapatan pedagang meningkat. Lokasi pasar Angsoduo Baru yang terelokasi membuat jalan Sultan Thaha yang terletak di depan pasar Angsoduo menjadi lancar dan tidak macet. Penerimaan pemerintah kota dan Propinsi Jambi meningkat karena adanya retribusi parkir. Aset pemerintah pun meningkat karena pembangunan pasar Angsoduo ini yang semula hanya lahan tidur

Kata Kunci : Relokasi, Dampak Sosial, Dampak Ekonomi

\section{PENDAHULUAN}

Pasar merupakan tempat pertemuan antara penjual dan pembeli. Pasar merupakan salah satu lembaga yang paling penting dalam ekonomi dan salah satu penggerak dinamika kehidupan ekonomi. Berfungsinya lembaga pasar tidak terlepas dari aktivitas yang dilakukan oleh penjual dan pembeli (Damsar dalam Yulianti, 2011: 3). Saat ini, pasar tidak hanya menjadi tempat terjadinya transaksi jual beli, tetapi pasar juga mulai dijadikan sarana penggerak perekonomian, dinamika perekonomian suatu 
kota ditentukan oleh seberapa jauh efisiensi penggunaan ruang atau pola penggunaan ruang untuk aktivitas perekonomian di kota tersebut. Perkembangan perekonomian kota ini secara spesifik akan ditentukan oleh dinamika sistem perdagangan yang ada di kota itu dan juga di kawasan sekitarnya (Kiik dalam Setyaningsih dan Susilo, 2014: 1).

Sampai saat ini, sarana perdagangan yang masih tetap eksis di lingkungan perdesaan maupun perkotaan adalah pasar tradisional. Ada 4 fungsi ekonomi yang dapat diperankan pasar tradisional, yaitu:

1. Pasar tradisional merupakan tempat dimana masyarakat dari berbagai lapisan memperoleh barang-barang kebutuhan harian dengan harga yang relatif terjangkau, karena seringkali relatif lebih murah dibandingkan dengan harga yang ditawarkan pasar modern. Dengan kata lain bahwa pasar tradisional merupakan pilar penyangga ekonomi masyarakat kecil.

2. Pasar tradisional merupakan tempat yang relatif bisa dimasuki oleh pelaku ekonomi lemah yang menempati posisi mayoritas, terutama yang bermodal kecil.

3. Pasar tradisional merupakan salah satu sumber pendapatan asli daerah, lewat retribusi yang ditarik dari para pedagang.

4. Akumulasi aktivitas jual beli di pasar merupakan faktor penting dalam perhitungan tingkat ekonomi baik pada skala lokal, regional maupun nasional.

Selain fungsi ekonomi di atas, pasar tradisional juga mempunyai fungsi sosial, yaitu:

1. Pasar tradisional merupakan ruang untuk saling bertemu muka.

2. Pasar tradisional adalah tempat bagi masyarakat, terutama dari kalangan bawah, untuk melakukan interaksi sosial dan tukar informasi atas segenap permasalahan yang mereka hadapi (Blokosuto, Edisi 02 dalam Endrawanti, 2012: 78-79).

Pasar tradisional umumnya menyediakan berbagai macam bahan pokok keperluan rumah tangga, dan biasanya berlokasi di tempat yang terbuka. Bangunan di pasar ini berbentuk Los/Lapak, toko dan kios. Los/Lapak pada umumnya digunakan untuk menjual aneka dagangan berupa sayur-sayuran, ikan, ayam potong, bumbu dapar dan lain sebagainya. Toko umumnya digunakan untuk berjualan aneka kue, pakaian, dan berbagai macam barang perabotan lainnya. Sementara kios digunakan untuk berjualan buah-buahan, sayuran, ikan, daging dan sebagainya.

Pasar Angso Duo terletak di Jalan Sultan Thaha Kelurahan Orang Kayo Hitam Kecamatan Pasar Jambi, di tepian sungai Batanghari. Keberadaan Pasar Angso Duo ini merupakan salah satu dari berbagai sumber peningkatan perekonomian kota Jambi, karena banyak masyarakat kota Jambi yang menggantungkan hidupnya dari penghasilannya sebagai pedagang di Pasar Angso Duo. Pasar ini tidak hanya melibatkan masyarakat kota Jambi saja sebagai penjual dan pembeli, tetapi juga masyarakat yang 
ada di luar kota Jambi, seperti masyarakat di Kabupaten Batanghari dan Kabupaten Muaro Jambi dan tidak menutup kemungkinan kabupaten lain yang letaknya cukup jauh dari kota Jambi. Hal ini dikarenakan pasar Angso Duo merupakan pasar induk kota Jambi dimana harga barang-barang yang dijual disini paling murah dibandingkan dengan pasar lain di kota Jambi.

Namun jika dilihat kondisi pasar Angso Duo ini cukup memprihatinkan. Air menggenangi sebagian besar permukaan pasar tua ini. Sistem drainase (pengeringan) yang gagal, acapkali dijadikan alasan sebagai penyebabnya. Pada bagian belakang, saking parahnya jalan, tak hanya pejalan kaki yang enggan melaluinya, bahkan kendaraan roda empat pun enggan lewat. Permukaan jalan di Pasar Angso Duo cukup parah, tidak beraspal dan lubang di mana-mana. Selain akses jalan yang sulit dan digenangi air, Pasar Angso Duo ternyata masih menyimpan masalah lain yakni kebersihan. Pasar yang terselip di antara bangunan-bangunan mewah ini, menampakkan wajah kumuh, kotor, sampah berserakan di mana-mana. Mulai sampah plastik, sampai sampah bekas dagangan yang tercecer di permukaan jalan. Selain itu, wajah Angsoduo kian parah akibat kesemrawutan lalu lintas yang berada di hadapannya. Pada jam-jam sibuk, yakni sekitar pukul 12.00 WIB, 14.00 WIB, 15.00 WIB dan 19.00 WIB, jalan Sultan Thaha yang melalui Pasar Angso Duo macet total. Kendaraan terpaksa jalan merangkak, kadang sampai tidak bisa jalan sama sekali. Soal parkir pun masih semrawut. Bahu jalan di jalur ke Angsoduo kini dipenuhi areal parkir dadakan. Pengunjung yang berniat berbelanja, terpaksa memarkir kendaraanya di daerah terdekat misalnya di bahu-bahu jalan seberang Pasar Angso Duo itu dikarenakan lahan parkir yang tidak mencukupi

Menyadari semrawutnya pasar tradisional Angso Duo ini, maka pemerintah kota Jambi mengambil kebijakan untuk merelokasi Pasar Angso Duo. Adapun lokasi yang dipilih untuk pembangunan pasar Angso Duo yang baru adalah sebuah lahan kosong yang memiliki luas sekitar 9 hektar yang terletak masih di tempat yang sama yaitu sebelah kanan pasar Angso Duo yang lama dan hanya berjarak sekitar 100 meter. Dan setelah melewati proses yang panjang dan dukungan semua pihak akhirnya pasar Angso Duo yang baru mulai dilakukan pembanngunan.

Dalam upaya menciptakan image baru di masyarakat tentang perubahan pasar Angso Duo ke pasar yang bernuansa modern maka pasar yang baru ini dinamakan "PASAR ANGSO DUO BARU”. Relokasi pedagang dari pasar Angso Duo ke Pasar Angso Duo Baru sendiri telah dilaksanakan mulai tanggal 11 November 2018. Relokasi Pasar Angso Duo ini bertujuan untuk menata lokasi perdagangan yang disesuaikan dengan barang dagangannya, sehingga lebih teratur dan tertib. Selain itu, relokasi ini juga bertujuan untuk meningkatkan 
kesejahteraan para pedagang di Pasar Angso Duo. Walaupun pemindahan lokasi pasar tidak jauh dari lokasi Pasar Angso Duo lama, namun tetap saja ada perbedaan yang dirasakan oleh para pedagang dan juga masyarakat yang melakukan kegiatan jual-beli di Pasar Angso Duo Baru. Adapun fokus dalam penelitian in adalah untuk menganalisis dampak sosial dan ekonomi dari pembangunan pasar yang baru bagi pedagang, masyarakat dan pemerintah.

\section{METODOLOGI PENELITIAN}

Penelitian ini berbentuk deskriptif kualitatif dengan tujuan untuk mendeskripsikan suatu gejala sosial dari objek yag diteliti dengan cara melakukan survei, wawancara dan penyebaran angket melalui teknik purposive random sampling. Lokasi penelitian dilakukan Jalan Sultan Thaha Kelurahan Orang Kayo Hitam Kecamatan Pasar Jambi. Semntara data yang digunkan dalam penelitian ini adalah data primer dan sekunder yang melibatkan semua pihak yang terkait dengan adanya relokasi pasar tersebut.

\section{Teknik Analisis Data}

Untuk menjawab permasalahan dampak sosial dan ekonomi akibat relokasi Pasar Angso Duo Baru, digunakan alat analisis skala likert. Menurut Noor (2012:128) skala likert "merupakan teknik mengukur sikap dimana subjek diminta untuk mengidentifikasi tingkat kesetujuan atau ketidak setujuan mereka terhadap masing-masing pertanyaan". Jawaban yang telah diberikan responden pada angket selanjutnya dihitung dengan menggunakan rumus persentase (\%) Sudijono (2003:40).

Keterangan:

$$
P=\frac{F}{N} x 100 \%
$$

$\mathrm{P}=$ persentase yang akan di capai

$\mathrm{F}=$ Jumlah jawaban benar

$\mathrm{N}=$ Jumlah sampel responden

Untuk itu perlu ditetapkan jumlah sampel yang diperlukan berdasarkan populasi yang ada. Populasi dalam penelitian ini adalah seluruh pedagang yang berjualan di Pasar Angso Duo Baru yang berjumlah sekitar 2800 pedagang. Penentuan jumlah sampel menggunakan rumus slovin. untuk mengetahui ukuran sampel representative yang di dapat berdasarkan rumus sederhana adalah sebagai berikut:

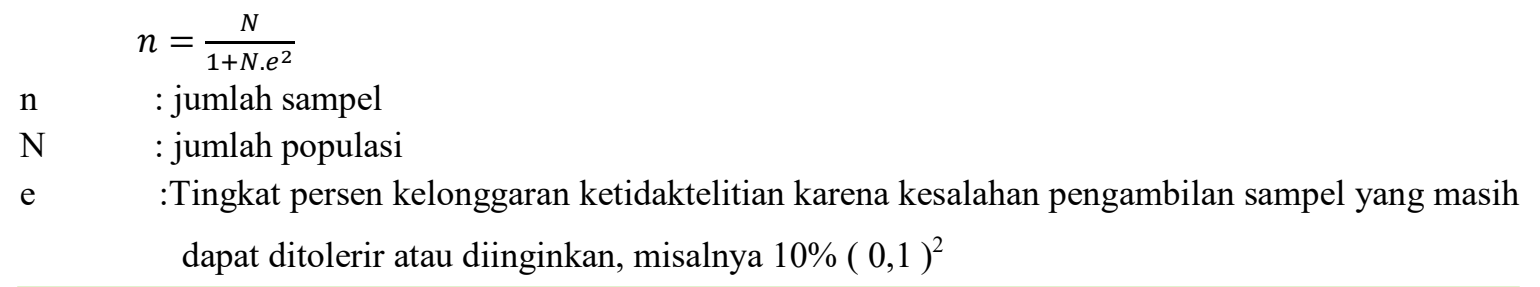




\section{HASIL PENELITIAN}

\section{A. Dampak Relokasi Pasar Angso Duo}

Dalam penelitian ini, dampak yang akan dibahas adalah dampak sosial dan ekonomi relokasi Pasar Angso Duo Baru ini terhadap pedagang, masyarakat dan pemerintah setempat.

\section{Dampak Sosial}

Untuk mengetahui dampak social yang dirasakan oleh pedagang karena relokasi Pasar Angso Duo Baru ini, maka kami melakukan wawancara dengan pedagang dan menyebarkan kuesioner kepada 60 pedagang dimana pedagang yang kami berikan kuesioner ini mewakili masing-masing jenis barang yang didagangkan.

\subsection{Dampak Sosial Pedagang}

\section{a. Hubungan Sosial Antara Sesama Pedagang}

\begin{tabular}{|c|c|}
\hline Sebelum Relokasi & Sesu \\
\hline $\begin{array}{l}\text { Hubungan antara sesama pedagang kurang terjalin dengan } \\
\text { baik, mengingat banyaknya pedagang kaki lima yang } \\
\text { menggelar barang dagangannya secara serampangan dan } \\
\text { ada juga yang menggangu jalan umum. Sebelum } \\
\text { direlokasi para pedagang cenderung memiliki sifat } \\
\text { individualis, para pedagang lebih mementingkan } \\
\text { bagaimana barang dagangannya laku dan kurang } \\
\text { memperdulikan pedagang lain apabila mengalami sepi } \\
\text { pembeli. Hubungan yang kurang baik ini diantaranya } \\
\text { karena infrastruktur yang jelek, jalanan becek dan kondisi } \\
\text { lapak yang cukup memprihatinkan sehingga pedagang } \\
\text { malas melakukan komunikasi dengan pedagang lainnya. }\end{array}$ & $\begin{array}{l}\text { Para pedagang terkonsentrasi di dalam pasar, } \\
\text { sehingga terbentuk pola interaksi yang baik. } \\
\text { Hubungan sosial terbentuk dengan baik meskipun } \\
\text { terjadi kompetisi antara pedagang dalam } \\
\text { memperoleh pelanggan. Selain itu terbentuk } \\
\text { kerjasama antara sesama pedagang dalam menjual } \\
\text { barang dagangannya. Kondisi infrastruktur yang } \\
\text { tersedia mendukung komunikasi yang baik antara } \\
\text { satu pedagang dengan pedagang lainnya. Lapak } \\
\text { dan jalan pedestrian yang bersih memungkinkan } \\
\text { pedagang untuk berkeliling sekedar mengobrol } \\
\text { dengan pedagang lainnya. }\end{array}$ \\
\hline $\begin{array}{c}\text { Hubungan Sesama P } \\
\text { Angso Duo Lama }\end{array}$ & $\begin{array}{l}\text { 3. } \\
\text { Hubungan Sesama Pedagang di } \\
\text { ar Angso Duo Baru }\end{array}$ \\
\hline
\end{tabular}

\section{b. Hubungan Sosial antara Pedagang dan Pembeli}

\begin{tabular}{|l|l|}
\hline Sebelum Relokasi & Sesudah Relokasi \\
\hline Hubungan sosial antara pedagang dengan pembeli & Hubungan sosial antara pedagang dan pembeli terjalin \\
kurang terjalin dengan baik karena pembeli kurang & dengan baik. Kondisi lapak dan pedestrian yang bersih \\
memiliki keterikatan dengan pedagang yang & membuat pembeli dapat leluasa berbelanja dan \\
seharusnya dapat menjadi langganannya dalam & memilih belanjaannya dengan tenang. Dari sisi \\
memenuhi kebutuhan. Adanya sebagian pedagang & pedagang sangat menguntungkan karena pada Pasang \\
yang menggelar barang dagangan sehingga & Angso Duo baru susunan lapak berdasarakan jenis \\
mengganggu jalan umum menyebabkan pembeli & barang dagangan. Kondisi pedestrian yang bersih \\
enggan untuk mendatangi pedagang yang seharusnya & memungkinkan pembeli dapat melewati semua \\
\hline
\end{tabular}




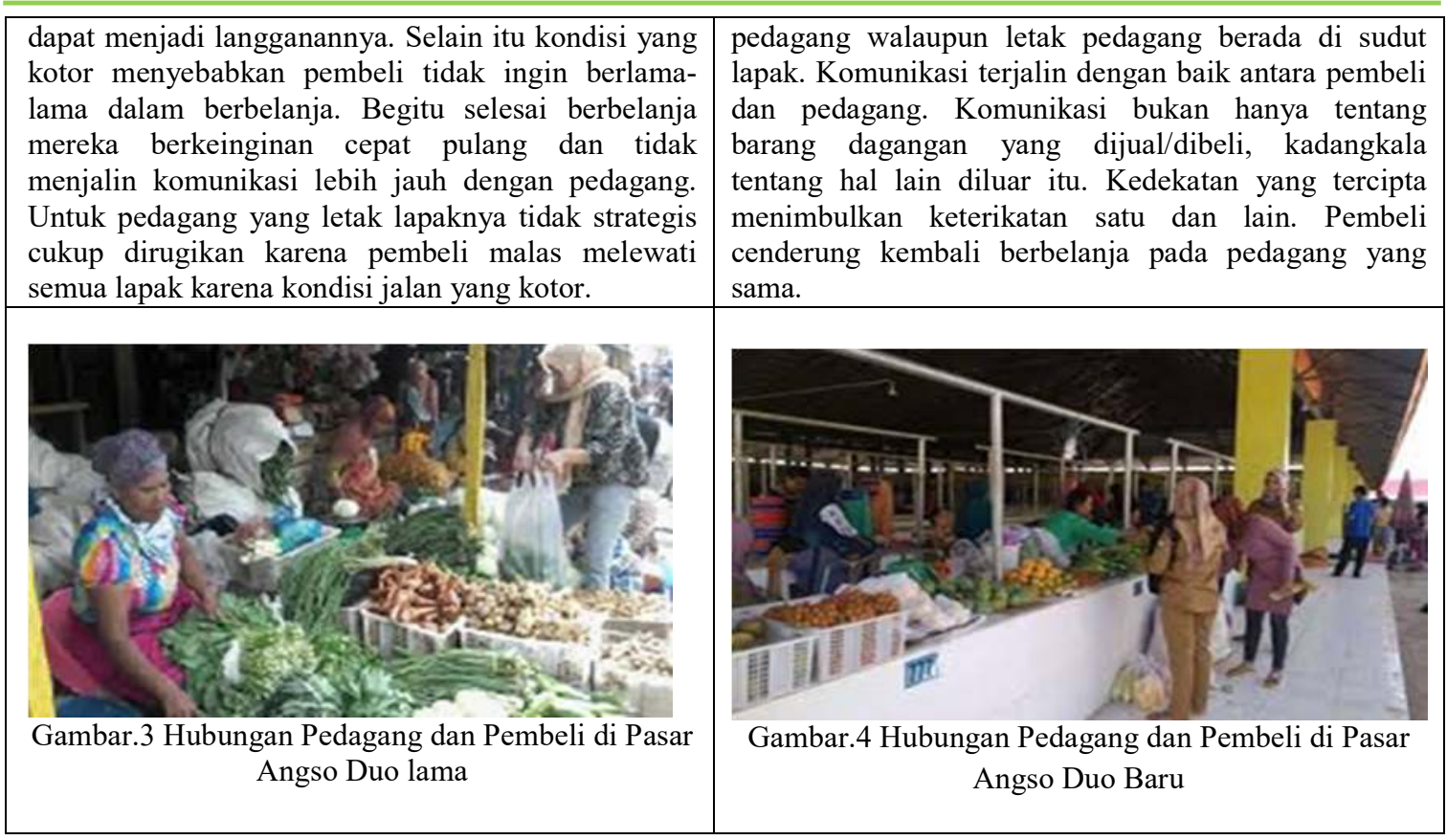

\subsection{Dampak Sosial Bagi Masyarakat}

\section{a. Tingkat Kemacetan}

\begin{tabular}{|l|}
\hline Sebelum Relokasi \\
\hline Pada jam-jam sibuk, yakni sekitar pukul 12.00 \\
WIB, 14.00 WIB, 15.00 WIB dan 19.00 WIB, jalan \\
Sultan Thaha yang melalui Pasar Angso Duo macet \\
total. Kendaraan terpaksa jalan merangkak, kadang \\
sampai tidak bisa jalan sama sekali. Soal parkir pun \\
masih semrawut. Lahan parkir yang tidak memadai \\
menyebabkan bahu jalan di jalur ke Angsoduo \\
dipenuhi areal parkir dadakan. Pengunjung yang \\
berniat berbelanja, terpaksa memarkir kendaraanya \\
di daerah terdekat misalnya di bahu-bahu jalan \\
seberang Pasar Angso Duo itu. Jalan Sultan Thaha \\
termasuk jalan utama dan penting yang harus \\
dilalui orang-orang dari arah broni, sipin, simpang \\
kawat yang ingin ke perbankan di jalan sutomo. \\
Jadi walaupun jalanan sering macet namun mau \\
tidak mau mereka harus melalui jalan tersebut
\end{tabular}

Berdasarkan kuesioner yang kami sebarkan ke masyarakat mengenai "Kondisi lalu lintas di Jalan Sultan Thaha-depan Pasar Angso Duo sangat lancar" di mana kami bagi menjadi 4 kategori yaitu tidak setuju, kurang setuju, setuju dan sangat setuju maka hasil yang kami dapatkan adalah $61 \%$ pedagang menyatakan tidak setuju, $18 \%$ pedagang menyatakan kurang setuju dan $12 \%$ yang menyatakan setuju, sementara tidak ada satupun yang menyatakan sangat setuju.

\section{Sesudah Relokasi}

Lahar parkir pasar Angso Duo Baru cukup luas, mampu menampung 500 - 600 kendaraan roda 2 dan $175-200$ kendaraan roda 4. Dengan kapasitas yang cukup besar tersebut, maka kendaraan pembeli yang ingin berbelanja di pasar Angso Duo Baru tidak perlu memakai bahu jalan untuk memarkirkan kendaraannya. Selain itu karena jumlah toko dan kios/lapak yang tersedia sekitar 3500 buah maka seluruh pedagang dapat tertampung di lapak/kios yang telah disediakan berdasarkan jenis dagangannya dan tidak perlu berjualan di sembarang tempat yang dapat mengganggu lalu lintas orang yang beraktivitas di sana. Selain itu karena letak pasar Angso Duo Baru yang terlokalisasi menyebabkan seluruh aktivitas di pasar Angso Duo Baru tidak mengganggu lalu lintas pengguna jalan. Kondisi ini menyebabkan jalan utama Sultan Thaha menjadi lancar pada jam berapapun.

Berdasarkan kuesioner yang kami sebarkan ke masyarakat mengenai "Kondisi lalu lintas di Jalan Sultan Thaha-depan Pasar Angso Duo sangat lancar" di mana kami bagi menjadi 4 kategori yaitu tidak setuju, kurang setuju, setuju dan sangat setuju maka hasil yang kami dapatkan adalah $82 \%$ pedagang menyatakan sangat setuju, $13 \%$ menyatakan setuju dan $2 \%$ menyatakan tidak setuju. Tidak ada satupun yang menyatakan kurang setuju

\section{b. Tingkat Kriminalitas}




\begin{tabular}{|c|c|}
\hline Sebelum Relokasi & Sesudah Relokasi \\
\hline $\begin{array}{l}\text { Kondisi pasar yang tidak begitu luas dan kapasitas } \\
\text { kios/lapak tidak sebanding dengan jumlah pedagang } \\
\text { yang ada menyebabkan pedagang liar berjualan di } \\
\text { bahu-bahu jalan. Lahan parkir dan pedestrian yang } \\
\text { sempit serta jalanan yang rusak parah menyebabkan } \\
\text { para pelaku pasar berjalan berdesak-desakan. } \\
\text { Kondisi yang ramai dan berdesak-desakan ini } \\
\text { memancing tindakan kejahatan. Apalagi sebagian } \\
\text { besar pembeli merupakan wanita yang selalu } \\
\text { dijadikan sasaran kejahatan, seperti copet, pencuri, } \\
\text { jambret dan lain sebagainya. }\end{array}$ & $\begin{array}{l}\text { Pasar Angso Duo Baru berdiri di atas lahan dengan } \\
\text { luas sekitar } 9 \text { hektar. Memiliki parkir yang cukup luas } \\
\text { dan disediakan pedestrian yang cukup lebar di sela-sela } \\
\text { toko dan kios/lapak. Hal ini memungkinkan pembeli } \\
\text { untuk dapat berjalan dengan leluasa tanpa harus } \\
\text { berdesak-desakan. Dari segi keamanan, kamera CCTV } \\
\text { yang selama } 24 \text { jam mengawasi segala gerak-gerik } \\
\text { orang yang beraktivitas di dalamnya menyebabkan } \\
\text { menurunnya kesempatan orang yang akan melakukan } \\
\text { kejahatan. Selain itu adanya petugas keamanan yaitu } \\
\text { satpam dan dibantu oleh polisi dan TNI yang } \\
\text { senantiasa berjaga di lokasi pasar. Pasar Angso Duo } \\
\text { juga dilengkapi mobil dan motor patrol yang senantiasa } \\
\text { berkeliling mengontrol kegiatan yang berlangsung di } \\
\text { pasar. }\end{array}$ \\
\hline $\begin{array}{l}\text { Berdasarkan kuesioner yang kami sebarkan ke } \\
\text { masyarakat mengenai "Tingkat kriminalitas di pasar } \\
\text { Angso Duo rendah" di mana kami bagi menjadi } 4 \\
\text { kategori yaitu tidak setuju, kurang setuju, setuju dan } \\
\text { sangat setuju maka hasil yang kami dapatkan adalah } \\
61 \% \text { pedagang menyatakan tidak setuju, } 18 \% \\
\text { pedagang menyatakan kurang setuju dan } 12 \% \text { yang } \\
\text { menyatakan setuju, sementara tidak ada satupun } \\
\text { yang menyatakan sangat setuju. }\end{array}$ & $\begin{array}{l}\text { Berdasarkan kuesioner yang kami sebarkan ke } \\
\text { masyarakat mengenai "Tingkat kriminalitas di Pasar } \\
\text { ANgso Duo Baru sangat rendah" di mana kami bagi } \\
\text { menjadi } 4 \text { kategori yaitu tidak setuju, kurang setuju, } \\
\text { setuju dan sangat setuju maka hasil yang kami } \\
\text { dapatkan adalah } 82 \% \text { pedagang menyatakan sangat } \\
\text { setuju, } 13 \% \text { menyatakan setuju dan } 2 \% \text { menyatakan } \\
\text { kurang setuju. Tidak ada satupun yang menyatakan } \\
\text { tidak setuju }\end{array}$ \\
\hline
\end{tabular}

\subsection{Dampak Sosial Bagi Pemerintah Kota Jambi}

Relokasi Pasar Angso Duo Baru yang dilakukan pemerintah kota Jambi pada bulan November 2018 lalu, membawa banyak perubahan positif yang dirasakan pedagang dan masyarakat. Usulan untuk melakukan relokasi ini telah lama direncanakan yaitu sejak kepemimpinan Gubernur Jambi Bapak Alm. Zulkifli Nurdin dan setelah mengalami proses yang cukup panjang yaitu kurang lebih 18 tahun, akhirnya pasar Angso Duo ini berhasil direlokasi ke tempat yang lebih baik.

Pasar semi modern yang dibangun di lahan dengan luas sekitar 9 hektar ini menampakkan bangunan yang besar dan megah yang atapnya berciri khas Jambi. Terdiri atas 2 bangunan besar berisi toko-toko, 2 bangunan besar berisi lapak/kios, 2 bangunan kecil toko. Pasar Angso Duo Baru ini merupakan pasar tradisional yang terbesar dan termegah di Propinsi Jambi.

Dampak sosial yang dirasakan pemerintah dengan relokasi pasar Angso Duo ini adalah timbulnya apresiasi kepercayaan dari masyarakat dan para pelaku pasar Angso Duo terhadap kinerja pemerintah. Pasar Angso Duo yang selama ini memberikan banyak masalah dan telah dirasakan oleh masyarakat selama bertahun-tahun akhirnya berhasil diatasi oleh pemerintah. Dahulu tingkat kriminalitas cukup tinggi, dimana kasus pencopetan, penjambretan, 
pencurian atau perkelahian sering terjadi di sana. Hal ini karena kondisi pasar Angso Duo lama yang mendukung terjadinya tindakan kejahatan. Selain itu tingkat kemacetan yang selalu terjadi di jam-jam sibuk membuat kondisi pasar Angso Duo semakin parah.

Namun kini, pasar Angso Duo Baru menjadi Ikon baru bagi masyarakat Kota Jambi. Pasar tradisional yang semi modern ini tampil lebih bersih, teratur, dan system pengelolaan pasar yang lebih baik. Pengelolaan pasar diserahkan ke pihak swasta yaitu PT. Eraguna Bumi Nusa, dimana dengan diserahkan ke pihak swasta maka diharapkan pendapatan pedagang meningkat, masyarakat nyaman dan aman berbelanja serta naiknya pendapatan bagi pemerintah.

Semua masalah yang mungkin timbul dengan adanya relokasi pasar ini telah diantisipasi sebelumnya. Pertama, dari segi pekerja, dengan direlokasinya pasar Angso Duo baru tidak menghilangkan mata pencarian orang-orang yang dulu pekerja liar di pasar Angso Duo lama. Misalnya tukang parkir, buruh panggul, tukang gerobak, ojek, tenaga keamanan bahkan "preman" yang mencari nafkah di sana. PT. Eraguna Bumi Nusa merekrut seluruh eks pekerja liar di pasar Angso Duo ini menjadi pekerja resmi dibawah binaan PT. Eraguna Bumi Nusa. Mereka dipekerjakan pada bagian-bagian yang diatur oleh PT. Eraguna Bumi Nusa dan mendapatkan gaji dengan system yang ditentukan oleh PT. Eraguna Bumi Nusa. Adapun jumlah pekerja yang dibawah binaan PT. Eraguna Bumi Nusa sebagaimana tercantum pada tabel di bawah ini :

Tabel.1 Jumlah pekerja terserap pada Pasar Angso Duo Baru berdasarkan jenis pekerjaan

\begin{tabular}{|c|l|c|}
\hline No & \multicolumn{1}{|c|}{ Jenis Pekerjaan } & $\begin{array}{c}\text { Jumlah tenaga kerja Terserap } \\
\text { (Orang) }\end{array}$ \\
\hline 1 & Petugas keamanan & 45 \\
\hline 2 & Petugas kebersihan & 35 \\
\hline 3 & Operator Kendaraan & 15 \\
\hline 4 & Petugas penertiban & 70 \\
\hline 5 & Pengatur parkir & 35 \\
\hline 6 & Ojek Ketek & 25 \\
\hline 7 & Ojek Motor & 40 \\
\hline 8 & Ojek Gerobak & 30 \\
\hline \multicolumn{2}{|c|}{ Total } & 295 \\
\hline
\end{tabular}

Sumber Data : PT. ERAGUNA BUMI NUSA

Semua pekerja ditempatkan pada bagian masing-masing. Untuk ojek ketek, ojek gerobak dan ojek motor masih tetap pada pekerjaannya. Sementara pekerja laki-laki yang berusia tua ditempatkan di bagian pengatur parkir atau petugas kebersihan. Sejauh ini eks pekerja ini bersyukur masih digunakan tenaga mereka di pasar Angso Duo Baru. Untuk pekerja 
laki-laki yang masih muda dan Eks "preman" ditempatkan di bagian keamanan. Walaupun mereka tidak memiliki sertifikat Pendidikan Dasar (Diksar) namun mereka diberikan alat bantu keamanan.

Kedua, Pemerintah juga tidak meninggalkan masalah pada eks pasar Angso Duo lama. Saat ini semua bekas bangunan pasar telah dirobohkan, dan rata dengan tanah. Agar tidak mengganggu aktivitas baik masyarakat sekitar maupun pekerja yang saat ini sedang membereskan sisa bangunan maka lahan eks pasar Angso Duo ini telah ditutupi oleh pagar seng. Ada wacana dari pemerintah bahwa lahan bekas pasar Angso Duo lama akan digunakan sebagai Ruang Terbuka Hijau (RTH). Lokasi yang strategis, di pusat kota, di pinggir jalan raya dan dipinggir sungai Batanghari menjanjikan pemandangan yang indah. Apalagi jika RTH nanti betul-betul didesign secara apik yang mengakomodir keinginan masyarakat untuk memiliki tempat bersantai bersama keluaga atau untuk mengekspresikan diri. Tempat hiburan bagi masyarakat kota Jambi selama ini memang cukup terbatas. Masyarakat kadang tidak tau harus pergi kemana lagi untuk menghabiskan waktu libur mereka. Kadangkala mereka harus pergi ke daerah lain untuk menikmati pemandangan atau fasilitas daerah lain yang belum dimiliki oleh kota Jambi.

\section{Dampak Ekonomi}

\subsection{Dampak Ekonomi Terhadap Pedagang}

Relokasi pasar Angso Duo ini pasti memberikan dampak ekonomi kepada para pelaku pasar termasuk pedagang. Untuk mengetahui dampak ekonomi yang dirasakan pedagang maka kami telah menyebarkan kuesioner kepada 60 pedagang yang mewakili semua jenis barang dagangan yang tersedia di sana.

\section{a. Pendapatan}

Berdasarkan kuesioner didapatkan data bahwa sejak pedagang pindah berjualan ke Pasar Angso Duo Baru, pendapatan mereka bertambah. Hal ini dapat disebabkan oleh beberapa hal, pertama, kondisi kios/lapak yang disusun berdasarkan jenis dagangan. Hal ini menguntungkan pedagang karena pembeli menjadi lebih terkosentrasi ke tempat yang dituju, tidak terpencar-pencar seperti dahulu sehingga pembeli dapat leluasa memilih barang yang diinginkan pada satu lokasi. Kedua, ukuran kios/lapak yang cukup besar memungkinkan pedagang untuk meningkatkan kapasitas barang dagangannya. Ketiga, pedestrian cukup lebar yaitu 2 - 3 meter sehingga pembeli dapat leluasa berjalan keliling sampai pada posisi toko/kios/lapak yang paling ujung sehingga besar kemungkinan semua pedagang dilewati oleh 
pembeli maupun lokasi pedagang tersebut di belakang dan di sudut. Keempat, Lokasi Toko/Kios/Lapak telah diatur sedemikian rupa dimana untuk blok yang berbentuk toko, setiap blok hanya terdiri dari 2 (dua) deret dimana toko yang paling ujung memiliki 2(dua) muka. Jarak antar toko cukup lebar yaitu 3-4 meter sehingga leluasa bagi pedagang menyusun barang dagangannya. Sementara untuk kios/lapak berbentuk berderet tanpa sekat dan semua kios/lapak menghadap ke depan. Kelima, berkurangnya retribusi liar yang selama ini banyak terjadi di pasar Angso Duo lama. Dengan berkurangnya retribusi maka pengeluaran menjadi berkurang.

Berdasarkan data kuesioner, pendapatan pedagang yang naik sebesar $0-5 \%$ sebanyak $85 \%$ dari total kuesioner dan $17 \%$ yang pendapatannya meningkat $6-10 \%$. Sementara pendapatan yang meningkatnya $>10 \%$ tidak ada.

\section{b. Jumlah Pembeli}

Berdasarkan kuesioner, jumlah pembeli meningkat sejak pasar Angso Duo di relokasi ke tempat baru. Ada beberapa hal yang dapat menyebabkan hal ini, pertama, Tempat yang bersih menjadi alasan pembeli untuk datang berbelanja di pasar Angso Duo Baru. Mereka tidak perlu menggunakan sepatu boot karena lokasi pasar bebas becek. Kedua, lahan parkir yang luas sehingga pembeli dapat bebas memarkirkan kendaraan di tempat yang telah ditentukan tanpa harus berdesakan dengan kendaraan lain ataupun memarkir kendaraan di bahu jalan yang membahayakan bagi pengguna lalu lintas jalan maupun bagi kendaraan itu sendiri. Ketiga, pengelompokan jenis dagangan sehingga pembeli dapat mudah menemukan dan memilih barang yang diinginkan hanya dapa satu lokasi. Keempat, bebas dari bau sampah karena pengelolaan sampah yang baik.

Berdasarkan kuesioner yang disebarkan ke pedagang, jumlah pembeli meningkat 1-5\% sebesar 33\%, jumlah pembeli meningkat sebesar 6-10\% sebesar $65 \%$ dan sisanya sebesar $2 \%$ menyatakan bahwa jumlah pembeli meningkat di atas $10 \%$.

\section{c. Retribusi}

Berdasarkan wawancara dengan PT. Eraguna Bina Nusa dan kuesioner yang kami sebarkan ke pedagang diperoleh informasi bahwa pedagang di Pasar Angsu Duo Baru ini tidak lagi membayar retribusi toko/kios/lapak karena bangunan milik sendiri. Mereka hanya diminta membayar listrik dan air sesuai dengan penggunaan masing-masing. Menurut PT. Eraguna Bina Nusa, ada potensi pengurangan retribusi bagi para pedagang sebesar Rp 60.000,-/hari. 
Jumlah ini cukup besar dan dengan ditiadakannya retribusi tempat ini akan mengurangi pengeluran pedagang dan pada akhirnya meningkatkan keuntungan bagi pedagang.

Sementara berdasarkan kuesioner yang diisi oleh pedagang, retribusi yang ada saat ini menurun dibandingkan dengan sebelumnya. Ada sekitar $72 \%$ pedagang yang menyatakan retribusi turun mulai $6-10 \%$ dan $28 \%$ pedagang yang menyatakan bahwa retribusi turun $1-5 \%$. Sementara penurunan retribusi lebih dari $10 \%$ tidak ada satupun pedagang yang menyatakannya.

\subsection{Dampak Ekonomi Terhadap Masyarakat}

Berdasarkan hasil wawancara dengan masyarakat sekitar, dampak ekonomi yang dirasakan sejak relokasi pasar Angso Duo ini adalah adanya penghematan biaya transportasi karena jalan sultan thaha yang bebas macet. Sebelum relokasi, jalan sultan thaha selalu mengalami macet karena adanya parkir liar pembeli yang akan berbelanja baik berbelanja di Pasar Angsoduo maupun yang akan berbelanja di sekitar toko yang tersedia di sana. Keterbatasan lahan parkir membuat masyarakat memarkirkan kendaraannya di sembarang tempat. Kemacetan ini juga disebabkan adanya pedagang kaki lima liar yang menempatkan gerobak dagangannya di lahan yang kosong atau tempat-tenpat parkir yang seharusnya digunakan untuk memarkirkan kendaraan.

\subsection{Dampak Ekonomi Terhadap Pemerintah Kota Jambi}

Ada banyak dampak ekonomi yang ditimbulkan dengan adanya relokasi Pasar Angso Duo terhadap pemerintah, yaitu :

\section{a. Peningkatan Aset Pemerintah Provinsi Jambi}

Sebelum beroperasinya Pasar Angso Duo Baru kondisi lahan milik Pemerintah tersebut hanya lahan kosong yang tidak produktif, karena kondisi lahan termasuk kawasan pasang surut. Dengan luas lahan sekitar $\pm 92.071 \mathrm{M}^{2}$ dan terletak d lokasi yang sangat strategis sebenarnya sungguh disayangkan jika lahan ini tidak menghasilkan apa-apa bagi pemerintah Provinsi Jambi.

Dengan adanya pembangunan pasar Angso Duo Baru di lahan yang semula tidak produktif ini maka menaikkan asset pemerintah provinsi Jambi yang semula hanya berupa lahan kosong menjadi lahan dengan bangunan sekitar 3500 toko/kios/lapak dengan nilai asset sekitar Rp 176.000.000.000,- (seratus tujuh puluh enam milyar rupiah). Semua aset tersebut adalah milik Pemerintah Provinsi Jambi karena status kepemilikan lahannya adalah milik pemerintah Provinsi Jambi. 
Sementara bangunan lama Pasar Angso Duo telah dirobohkan secara keseluruhan karena memang bangunan tersebut sudah tidak memiliki nilai ekonomi lagi. Dengan adanya wacana penggunaan lahan eks pasar Angso Duo ini sebagai Ruang Terbuka Hijau (RTH) akan menaikkan kembali asset pemerintah Provinsi Jambi karena di sana akan dijadikan Ruang Terbuka Hijau (RTH).

\section{KESIMPULAN DAN SARAN}

\section{Kesimpulan}

1. Dampak sosial yang ditimbulkan karena relokasi pasar Angsoduo adalah berdampak positif, yaitu :

a. Hubungan antara sesama pedagang lebih baik. Kondisi infrastruktur yang tersedia mendukung komunikasi yang baik antara satu pedagang dengan pedagang lainnya.

Lapak dan jalan pedestrian yang bersih memungkinkan pedagang untuk berkeliling sekedar mengobrol dengan pedagang lainnya.

b. Hubungan sosial antara pedagang dan pembeli terjalin dengan baik. Kondisi lapak dan pedestrian yang bersih membuat pembeli dapat leluasa berbelanja dan memilih belanjaannya dengan tenang. Komunikasi terjalin dengan baik antara pembeli dan pedagang. Komunikasi bukan hanya tentang barang dagangan yang dijual/dibeli, kadangkala tentang hal lain diluar itu. Kedekatan yang tercipta menimbulkan keterikatan satu dan lain.

2. Dampak ekonomi dari relokasi pasar Angsoduo adalah:

a. Pendapatan pedagang bertambah dikarenakan, pertama, kondisi kios/lapak yang disusun berdasarkan jenis dagangan sehingga pembeli dapat leluasa memilih barang yang diinginkan pada satu lokasi. Kedua, ukuran kios/lapak yang cukup besar memungkinkan pedagang untuk meningkatkan kapasitas barang dagangannya. Ketiga, pedestrian cukup lebar yaitu 2 - 3 meter sehingga pembeli dapat leluasa berjalan keliling sampai pada posisi toko/kios/lapak yang paling ujung sehingga besar kemungkinan semua pedagang dilewati oleh pembeli maupun lokasi pedagang tersebut di belakang dan di sudut. Keempat, berkurangnya retribusi liar yang selama ini banyak terjadi di pasar Angso Duo lama. Dengan berkurangnya retribusi maka pengeluaran menjadi berkurang. Kelima, jumlah pembeli yang meningkat.

b. Dampak ekonomi yang dirasakan masyarakat adalah adanya penghematan biaya 
transportasi karena jalan sultan thaha yang bebas macet. Sebelum relokasi, jalan sultan thaha selalu mengalami macet karena adanya parkir liar pembeli yang akan berbelanja baik berbelanja di Pasar Angsoduo maupun yang akan berbelanja di sekitar toko yang tersedia di sana.

c. Dampak ekonomi yang ditimbulkan dengan adanya relokasi Pasar Angso Duo terhadap pemerintah, yaitu adanya peningkatan aset pemerintah provinsi jambi sekitar Rp 176.000.000.000,- (seratus tujuh puluh enam milyar rupiah). Selain itu adanya peningkatan penerimaan pemerintah dari Retribusi Parkir. Selain itu ada penerimaan lainnya seperti penerimaan PBB, IMB, PPHTB, dan lain sebagainya.

\section{Saran}

1. Agar pasar Angsoduo Baru terus memberikan dampak sosial dan ekonomi postif maka perlu penganggaran biaya pemeliharaan yang cukup agar kondisi pasar Angsduo yang bersih tetap terjaga

2. Pengelolaan sampah secara modern agar dampak negative yang ditimbulkan oleh sampah tidak terjadi

3. Melakukan pengawasan yang ketat terhadap oknum-oknum yang masih melakukan pemungutan retribusi liar agar pendapatan pedagang menjadi meningkat karena pengeluaran untuk retribusi liar sudah tidak ada lagi.

\section{DAFTAR PUSTAKA}

Aprilliyani, R., \& Rubyah, H. (2012). Analisis Faktor Perilaku Konsumen Pasar Tradisional, Gemawisata, 10(1).

Eliyani., Dwi,. \& Nurhadi. (2012). Dampak Relokasi Pasar Imogiri Terhadap Kondisi Sosial Ekonomi Pedagang Di Pasar Imogiri Kecamatan Imogiri Kabupaten Bantul. E Jurnal Universitas Negeri Yogyakarta. 1(1).

Heriyanto.,\& Aji, W. (2012). Dampak Sosial Ekonomi Relokasi Pedagang Kaki Lima Di Kawasan Simpang Lima Dan Jalan Pahlawan Kota Semarang. Economics Development Analysis Journal. 1(1) 1-6.

Hasbuan., \& Nurul, A. (2017) Analisis Dampak Relokasi Pasar Tradisional Terhadap Pendapatan Pedagang Sebelum Dan Sesudah Relokasi Ke Pasar Induk Di Kota Medan (Studi Kasus Pasar Sutomo Medan). Skripsi Thesis, Universitas Islam Negeri Sumatera Utara.

Permen Perdagangan RI No70/Mdag/Per/12/2013 Tentang Pedoman Penataan Dan Pembinaan Pasar Tradisional, Pusat Perbelanjaan Dan Toko Modern. 
Setyaningsi, A. (2014). Dampak Sosial Ekonomi Relokasi Pasar Satwa Kasus Pasar Satwa Dan Tanaman Hias Yokyakarta (Pasty) Universitas Atma Jaya Yokyakarta: Ekonomi Pembangunan, Fakultas Ekonomi Universitas Atma Jaya.

Suharno. (2010). Dasar-Dasar Kebijakan Publik: Kajian Proses Dan Analisis Kebijakan. Yokyakarta. Uny Press. 